\title{
History of the Psychonomic Society II: The journal publishing program
}

\author{
DONALD A. DEWSBURY \\ University of Florida, Gainesville, Florida
}

\begin{abstract}
The possibility of a Psychonomic Society journal publishing program dates back to the very founding of the Society in 1959. The program was initiated by Clifford T. Morgan on his own, however, with the publication of Psychonomic Science in 1964, followed by Psychonomic Monograph Supplements and Perception \& Psychophysics within the next 2 years. In 1967, Morgan gave the journals to the Psychonomic Society, which has controlled them ever since. The structure of the journal program and the means of producing the journals have evolved since then, so that today the Psychonomic Society publishes six prominent journals in experimental psychology, all of them produced in-house.
\end{abstract}

The Psychonomic Society now publishes six major journals in experimental psychology: Animal Learning \& Behavior, Behavior Research Methods, Instruments, \& Computers, Memory \& Cognition, Perception \& Psychophysics, Psychobiology, and the Psychonomic Bulletin \& Review. The publication program is unusual, in that virtually all steps in the publication process are done inhouse. The path from the founding of the Society to the Society's present structure, reviewed herein, has not always been smooth, however.

The Psychonomic Society was founded in December 1959 in an effort to improve communication among experimental psychologists (see Dewsbury \& Bolles, 1995). After a number of discussions and some initial efforts, an Organizing Committee was formed; it met in Chicago, where members hammered out an agreement on the essential features of the new society.

The possibility of journal publication was in the minds of the founders of the Psychonomic Society from the beginning. In the initial letters of invitation to potential members of the new Organizing Committee, it was proposed that the new society should have just two purposes: to conduct annual meetings and to publish journals (Verplanck, 1959a).

The possibility of journal publication received much attention at the Chicago meeting of the Organizing Committee. Clifford T. Morgan, who would become the first

There are many people to thank for help with this project: the whole Austin staff, who were so hospitable during my visit and who tolerated my interviews; the staff at the Archives of the History of American Psychology at the University of Akron; the members of the Psychonomic Society who answered my many questions and provided essential documents; the past Secretary-Treasurers who preserved their materials; Roddy Roediger, who initiated the project; the late Bob Bolles, who had started on a project like this before his death; and Peter Gianaros, who helped gather detailed material from the journals. I thank David Ehrenfreund, Anne Dossett, Rob Sanford, and Ellen Woodard for their comments on an earlier draft of this article. Correspondence should be addressed to D. A. Dewsbury, Department of Psychology, University of Florida, Gainesville, FL 32611-2065 (e-mail: dewsbury@psych.ufl.edu).
Chairman of the Governing Board and who was at the time the Chairman of the APA Board of Publications, argued strongly for a publication program for the new society. Another member of the Organizing Committee, Benton J. Underwood, was strongly opposed (Verplanck, personal communication, October 27, 1994). As a compromise, Article VII of the Bylaws of the new society was noncommittal:

The society shall publish such programs, abstracts of scientific papers, and lists of membership, as the Governing Board shall authorize. With approval of the membership, the Governing Board may undertake the editing, or publishing, or both, of scientific journals. (Dewsbury \& Bolles, 1995, p. 230)

There was good reason for the Society to be concerned with publication-related issues; its members were frequent contributors to the literature. Indeed, they were selected as members partly because they tended to publish. In a study conducted soon after the Psychonomic Society was founded, Woods (1961) analyzed patterns in APA publications and comparable journals for 1959 . The mean number of publications per Psychonomic Society member in these journals was higher than the mean number for members of any of the APA divisions. Psychonomic Society members authored $33 \%$ of the articles in the Journal of Experimental Psychology, 31\% in the Journal of Comparative and Physiological Psychology, and a remarkable $48 \%$ of the articles in the Psychological Review. Clearly, Psychonomic Society members were heavy publishers and were not withdrawing from APA publications.

On the other hand, the founders wanted to proceed slowly, because they recognized the inherent instability of a new organization and the financial liability involved in publishing endeavors.

\section{EARLY EFFORTS TOWARD A PUBLISHING PROGRAM}

The first phase of the process of establishing the journal program consisted of a number of overtures to and from 
various publishers in an effort to find a publishing outlet that would create a minimum of Psychonomic Society bureaucracy. The Governing Board wanted to improve the publishing situation for experimental psychologists but did not want to follow the American Psychological Association (APA) in building a large administrative structure.

In the summer of 1959 , prior to the meeting of the Organizing Committee, Secretary-Treasurer William S. Verplanck had already contacted Parker Lichtenstein of Denison University about the possibility that the Psychological Record might become the official journal of the new society (Verplanck, 1959b).

At the Chicago meeting, it was decided that members of the Governing Board would explore several other possibilities. Clarence H. Graham met with Carl Murchison, publisher of his own set of journals, to see whether the Journal of General Psychology might assume such a role. Murchison proposed that he might publish a supplementary volume of the Journal of General Psychology that would be specially labeled as originating in the Psychonomic Society (Graham, 1960). The Governing Board elected to defer a decision on this possibility (Governing Board Minutes, September 1960). ${ }^{1}$ Murchison died on May 20, 1961.

Morgan approached Karl Dallenbach concerning possible arrangements with the American Journal of Psychology (Verplanck, 1960). Eventually, it became clear that Dallenbach did not want to sell the journal; he gave it to the University of Illinois in 1968 (Morgan, undated).

W. Hayward ("Buck") Rogers, an editor at the Academic Press, met with the Board at its 1961 New York meeting and proposed to the Governing Board that the Psychonomic Society edit one or more journals in experimental psychology to be published by the Academic Press. The Board turned down this proposal, believing that it was more important to improve the quality of existing journals than to found new ones.

The first ad hoc Publications Committee was appointed in the fall of 1961 (Governing Board Minutes, 1961). Morgan, Graham, Underwood, and Verplanck (ex officio) would work with potential publishers. At the annual business meeting, sensing the possibility that rapid action might be necessary, the membership approved a motion "that the Governing Board be empowered to complete arrangements for editing and publishing a journal or journals under conditions involving no financial obligations by individual members of the Psychonomic Society" (Business Meeting Minutes, August 31, 1962). Things seemed to be moving ahead.

Meanwhile, it became known that Mrs. Murchison was interested in selling the Murchison journals. Academic Press proposed to buy the Murchison journals on the condition that the Psychonomic Society edit them. Academic Press was willing to pay up to $\$ 325,000$ for the journals, but Mrs. Murchison believed them worth $\$ 500,000$. The negotiations failed (Morgan, undated).

In the meantime, Academic Press moved ahead with its publishing program with the founding of the Journal of Verbal Learning and Verbal Behavior. Plans were made to convert Richard Atkinson's Studies in Mathematical Psychology into the Journal of Mathematical Psychology. In the spring of 1962, Morgan, who had been a Consulting Editor for McGraw-Hill's Series in Psychology, joined Academic Press as a Consulting Editor. In the fall of 1963, however, Rogers was fired by Academic Press and Morgan immediately resigned because he had accepted the appointment only because he felt that he could work well with Rogers. Lawrence Erlbaum assumed Rogers's position (Morgan, undated).

The final result of all of this activity was that the Psychonomic Society was without a journal and the energetic Morgan was now on his own. Morgan would not let negotiations for a journal program rest in the unsettled condition they had reached. He had the interest, ability, determination, and resources to strike out on his own.

\section{THE START OF THE PUBLISHING PROGRAM}

A fundamental fact to remember in attempting to understand the publishing program of the Psychonomic Society is that publication of the journals began outside of the society, with the individual efforts of Clifford T. Morgan. Although the Society had worked to establish a program, it was Morgan, working on his own, who actually accomplished the feat. Even today, the Psychonomic Society's publication program has more autonomy from the Governing Board than would be found in other organizations.

\section{Clifford T. Morgan, Publisher}

Clifford T. Morgan (1915-1976) had had an interesting career (Garner, 1976; Melton, 1976). A 1937 University of Rochester PhD, he had served on the faculties at Harvard University and the Johns Hopkins University, where he became chair. Morgan resigned as chair in 1956. According to Garner, Morgan was a very well-organized man, with a low tolerance for inefficient systems and people who were not well organized. This could cause problems in a university administrative situation. While he had been at Johns Hopkins, the writing of textbooks had become Morgan's primary endeavor. He had already written the successful Physiological Psychology in 1943, and his new Introduction to Psychology was a huge success. The book "made Cliff independently wealthy. Never again was Cliff to be dependent on a university for his salary" (Garner, 1976, p. 412). He resigned his professorship, accepting the courtesy title of Fellow of the University in 1957 , and "so Cliff became a free-roaming scientist, able to live and work where he wanted, with no problems of conflict about administrative work" (Garner, 1976, p. 412). He was no longer a researcher and professor, but a writer.

Morgan moved to Madison, Wisconsin, in 1959, Santa Barbara, California, in 1962, and Austin, Texas, in 1967. The last move was made, in part, to be with the family of his brother-in-law, Texas psychologist Fillmore H. San- 
ford, upon Sanford's death on August 6, 1967 ("Dr. Fillmore Sanford," 1967). At the University of Wisconsin, University of California, Santa Barbara, and University of Texas, Morgan participated in many faculty activities, giving courses and serving on students' committees, but avoiding administration.

With his experience as a consulting editor for publishers, a textbook author, a member of the APA's Publications Board, as editor of the Psychological Abstracts, Morgan had learned much about the publishing business.

\section{The Founding of Psychonomic Science}

Morgan's publishing program came to fruition with the first number of Psychonomic Science in 1964. The new journal would publish "brief reports of research with a very short publication lag" (Morgan, 1964a).

The apparent origin of this idea lies in a report from the APA Board of Scientific Affairs (BSA) on the problems of technical communication in psychology (BSA, 1959). Traditionally, scientific communication in psychology had worked effectively with a combination of professional meetings for the rapid communication of fundamentals and archival journals that preserved the detailed information for the long term. This arrangement was becoming strained as the field grew. The BSA saw the major journals in the field already publishing twice the number of articles they had in the previous decade; publication lags were increasing. They noted that "the need for rapid communication of messages to other research workers concerned with the same problem area... becomes ever more important as the rate of acquisition of scientific knowledge increases" (Board, 1959, p. 268). The BSA proposed that "perhaps a publication like the brief reports section of Science would be appropriate, if an attempt were made to serve all of scientific psychology by a single publication" (p. 269). The BSA considered "the problem of efficient communication of scientific information to be perhaps the most critical problem faced by scientific psychology today" (p. 270).

Morgan simply took the bull by the horns and founded a journal in the image of that proposal. I have found no information concerning the precise time at which Morgan decided to take this bold step. In October 1963, soon after departing from Academic Press, he wrote to members of the Governing Board informing them of his intention to publish a new journal (Morgan, 1963). There is no indication that he discussed this with the Board; he simply did it on his own and informed them later. Morgan hired Rogers as the Managing Editor and announced that the journal would be published in Santa Barbara. An effort would be made to hold costs down, with an initial subscription price of $\$ 5.00$.

In his opening editorial, citing the BSA report, Morgan (1964a) explained the need for another journal as a means of rapid communication of results of scientific research in psychology. Morgan explained that the articles should be brief in order to hold down costs and to save both time and money. He therefore set a 1,200-word limit on articles, the model being the brief reports section in Science magazine.

How would Morgan achieve the rapidity of publication that he sought? First, he would minimize the editorial review process. Many articles would be published after only a review by Editor Morgan; others would be delayed just a week as they were referred to consultants. He recognized that mistakes would be made, but preferred them to publication delays. Morgan promised a "Comments" section that might address weak articles. To speed up the publishing, he would use "a combination of photographic methods for headings and illustrations, cold-type composition, and photo-offset printing. The final product does not look quite as nice as the letterpress composition and printing, but it is fully as readable and as usable" (Morgan, 1964a, p. 2). Clearly, Morgan placed a premium on speed. The publication lag from acceptance to publication was to be about 1 month. The honor of being the first article to appear in the publishing history went to Lindzey, Winston, and Whitney (1964) for a study of defecation in mice in stressful and nonstressful situations. The first number also contained articles by such familiar names as Tracy and Howard Kendler, Leo Hurvich and Dorothea Jameson, M. E. Bitterman, Robert Bolles, M. R. D'Amato, and Lewis Lipsitt.

The plan was to publish 12 monthly issues, each with 16 articles or 32 pages, for a total of 384 pages. In fact, Morgan published 416 pages, as issues went from 16 to 20 to 29 articles in the 1st year. Morgan (1964b) announced a plan to publish prepublication abstracts of articles to appear in slower journals than his. He then announced plans to go to a twice-monthly publication plan for 1965 (Morgan, 1964c) and published two volumes with a total of 976 pages in 1965, three volumes in 1966 and 1967, and four volumes in 1968.

The staff listed in the first issue included Morgan as Editor, Rogers as Managing Editor, and Jean S. Morgan as Assistant to the Editor. Rogers left and Shirley Dods joined the staff in November 1964. With the beginning of Volume 3, the journal was published by the "Psychonomic Press," rather than by Clifford T. Morgan. By 1967 , there was an 11-person (full- and part-time) staff.

In 1965, Morgan (1965) announced that he was beginning to segregate articles in different issues of the journal so that those dealing with animal and physiological areas and with human experimental areas would be different. Beginning with Volume 5 (1966), one could subscribe to the whole journal or just one of its sections: Human Experimental Psychology or Animal and Physiological Psychology. By 1968, Morgan was publishing four volumes a year and a total of 1,524 pages. The venture was a success!

\section{Expanding the Publishing Endeavor}

Buoyed by the success of Psychonomic Science, Morgan moved into the publication of longer articles with the Psychonomic Monograph Supplements, which he founded the next year. Volume 1, which included 16 articles, was 
spread over 1965 and 1966. The first article published was a paper on "Procedural Problems in Paired-Associate Learning Research" by William F. Battig. The first volume contained 416 pages.

In 1966, Morgan added yet another journal, Perception \& Psychophysics, originally to be entitled the Journal of Perception and Psychophysics. Morgan (1966) was somewhat apologetic for adding yet another journal to the field, but explained that with the long publication lags for articles in sensation and perception, the increasing number of people working in the area, and the increasing availability of funding, "the waters" were "pushing hard against the dam" (p. 1). Morgan would serve as Managing Editor for the new journal with an eight-member Editorial Board, half of whom had been on the original Organizing Committee of the Psychonomic Society.

Morgan branched out yet again in the following year as the Psychonomic Press began the publication of books. Morgan published Classical Conditioning by Robert $\mathrm{S}$. Beecroft (1966), a Laboratory Manual for Physiological Psychology by William E. Wilsoncroft and O. Thomas Law (1967), and Experimental Studies of Schizophrenia by Carmi Schooler and Solomon E. Feldman (1967). This aspect of Morgan's publishing efforts did not expand the way the others did, and he published just two additional monographs some years later (Geldard, 1973; Hearst \& Jenkins, 1974).

\section{The Publishing Program in California}

The publishing endeavor in California was largely a family affair. During the 1st year or so, the typesetting and printing were sent out; but this was expensive, and, after that, all was done in-house. This can be interpreted quite literally, as the work was done in Morgan's home, though several other locations in the area were later occupied (M. Morgan, 1995). A garage was converted to bedrooms to make more office space in the house. The program was run at first in Goleta, a small town just north of Santa Barbara, with a growing staff as noted above; five of the workers were named Morgan. Clifford's second wife, Jean, dealt with subscriptions and helped with typesetting. Patricia Morgan, Clifford's daughter, became a typesetter. Peter and Michael Morgan worked as printer's helpers, and then as printers. From the beginning, Morgan allowed his workers, including his family, to work whatever hours they chose as long as the work got done (M. Morgan, 1995; P. Morgan, 1995). A similar flexibility of hours is still seen in the Psychonomic Society publishing program in Texas.

The equipment used was primitive by today's standards, and this made the process of typesetting more delicate and involved than today. When Anne Matson Dossett joined the operation in 1965, the team that did the typesetting and pasteup comprised Jean and Pat Morgan along with Dossett. Anne Dossett was a mainstay of the Psychonomic Society operation for some 30 years (End of an Era, 1993; Dossett, 1995).

\section{The Move to Austin}

When Fillmore Sanford died on August 6, 1967, Clifford and Jean Morgan went immediately to Austin to be with Ann Sanford. When they returned to Goleta, they informed those in California that they had decided to move to Austin, in part to help Ann. Also, Morgan seemed concerned about the effects of the California lifestyle on his children (M. Morgan, 1995). When they moved from California, the journal production operation, including typesetting, proofreading, and pasteup, was left in California with Anne Dossett. The business end and some of the editorial work moved to Austin.

Although coordination of the operation between Austin and California worked fairly well, the process was more difficult than when all were together. On one visit to California, Morgan suggested to Dossett the possibility that she might move to Austin so that the whole operation could be unified once more, and in 1970 the publication operation was reunified, now in Austin.

In 1968 Morgan hired Sharon Tarver, who had been Fillmore Sanford's secretary and had experience working at Contemporary Psychology, to work for the Psychonomic Society. In 1969, he added Ann Sanford as Managing Editor. In 1974, Morgan would hire C. E. Wheeless, who had experience printing for the city of Austin, as his first professional printer. He succeeded various Morgans and Sanfords who had done much of the printing. Wheeless would remain on the staff until the end of 1993, providing stability and professional reliability for this important aspect of the journal operation (see End of an Era, 1993).

\section{THE GIFT}

In 1967, Clifford T. Morgan gave his journal operations to the Psychonomic Society as a gift, as may have been his plan all along. Reconstructing these events is a bit difficult; although Clifford T. Morgan probably did more for the Psychonomic Society than any other person, preparing minutes of Governing Board meetings during his term as Secretary-Treasurer was not one of his contributions. Fortunately, however, a document written by David Ehrenfreund (1977) is of great value in this respect.

Although acceptance of a valuable gift would seem straightforward, the reader should appreciate what a major step this was for the Governing Board. The Psychonomic Society had been founded in order to facilitate communication among experimental psychologists primarily through its meetings. The founders were emphatic in wishing to avoid the bureaucratic complexity of the APA. All was run on an efficient and minimalist basis (see Dewsbury \& Bolles, 1995). Entry into the journal publishing business thrust the Society into a whole range of spheres, such as tax complexities, personnel matters, equipment purchasing, and maintenance, that must have scared Governing Board members as they saw trends toward the larger APA-like structure. This was a step away from some fun- 
damental guiding principles of the Psychonomic Society. There was much debate, but, in the end, the decision was to go ahead.

In December 1966, Morgan wrote to the Governing Board, explaining that he would soon have a proposal ready for the Society to take over publication of his journal program. At this time, Rogers, now back with Academic Press, had a concrete proposal for a Journal of Conditioning and Learning, which it wanted under the editorial control of the Society. Both proposals were discussed at a spring 1967 meeting of the Governing Board in Urbana, Illinois. Morgan returned with a revised proposal. In his letter to Judson S. Brown, Chair of the Governing Board, of May 2, 1967, he indicated that he had not made his intention to give the journals to the Society a definite proposal at the spring meeting because he wanted the Governing Board to give the Academic Press proposal a fair hearing without distraction from him. Morgan thus made "Proposal 2," which would give the journals to the Society:

Clifford T. Morgan, owner of Psychonomic Press, proposes to give to the Psychonomic Society all his interest in the three journals he now edits and publishes: Psychonomic Science, Perception \& Psychophysics, and Psychonomic Monograph Supplements. This gift will include all equipment in use and on order, all materials used in the production of the journals, all inventory, and sufficient cash $(\$ 10,000)$ to provide ample operating capital. It will not include the books published by Psychonomic Press. Total value of the gift will be $\$ 60,000$ to $\$ 70,000$. (Morgan, 1967)

In order to avoid tax problems, the gift would be spread over 3 years, but by January 1, 1968, the Society would be in complete control of the journals. The journals were now solvent and turning a profit. Morgan thought it possible for the Society to add a new journal, Conditioning $\&$ Learning, in the immediate future.

The Governing Board accepted the offer on October 7 , 1967 (Ehrenfreund, 1977). However, the Governing Board had one more trick up its sleeve in its efforts to avoid financial obligations. The Board asked its SecretaryTreasurer (Morgan!) to establish a separate corporation that would be responsible for journal publication, thus removing responsibility from the Society itself.

In the midst of all of this maneuvering and legal activity, Morgan decided to add another journal. Behavior Research Methods \& Instrumentation began in 1968 under the editorship of Joseph B. Sidowski (Sidowski, 1968). Morgan (1968) had bigger plans, however. He wanted to establish a Journal of Experimental Psychopathology and a journal of rapid-publication reports in experimental developmental psychology, as well as to provide for the publication of book reviews either in a new journal or in existing journals and to make various changes in Psychonomic Science. At this point, Morgan already was floating the idea that Psychonomic Science might be broken down into several journals; even with 1,600 pages a year, there was pressure on the journal.
Psychonomic Journals Inc. was incorporated in the State of Texas on August 6,1968, the incorporators being Morgan, Ann L. Sanford, and Gardner Lindzey; it assumed operation of the journals on October 1. Thus, the Society actually published the journals from January 1 through the end of September 1968. The assets donated by Morgan remained with the Society while the taxexempt status of Psychonomic Journals was established. A set of bylaws was constructed. The original Board of Directors comprised William J. McGill, Charles N. Cofer, Arthur W. Melton, Richard F. Thompson, Richard J. Herrnstein, Richard C. Atkinson, and Clifford T. Morgan.

The situation got complicated when the Internal Revenue Service denied the application for tax-exempt status because inasmuch as Psychonomic Journals Inc. was "organized and operated to carry on the business of publishing journals, it cannot be said that you are organized and operated exclusively for educational and scientific purposes" (Phinney, 1970). At its November 1970 meeting in San Antonio, the Governing Board of the Psychonomic Society and the Board of the Journals voted to dissolve Psychonomic Journals Inc. and henceforth for the Society to publish the journals. As provided by the bylaws, the matter was brought to the business meeting, where it was approved (Governing Board Minutes, November 1970). The right to do business in the State of Texas was transferred back to the Psychonomic Society, Inc. on October 1, 1971 (Ehrenfreund, 1977).

\section{THE PSYCHONOMIC SOCIETY AS PUBLISHER}

The Psychonomic Society had gotten its hands dirty and was now in the publishing business. Morgan would wield a strong hand for the first few years, but the program would see major change in the $1970 \mathrm{~s}$.

\section{Reshaping the Stable of Journals}

At its 1970 San Antonio meeting, the Board made several other important decisions that would restructure the publications program. Morgan was appointed Editorin-Chief of the journals and Ann L. Sanford was appointed Managing Editor. They would oversee the journals operation, but much of the burden was lifted from Morgan's shoulders with a variety of other actions: (1) It decided that the terms of editors would be for 4 years, with reappointment to only one additional term permitted. (2) Psychonomic Science would become a fully edited journal for short articles with rapid publication. Four coeditors, two for each section, would be appointed. (3) Joseph Sidowski would continue as editor of Behavior Research Methods \& Instrumentation. (4) A principal editor for Perception \& Psychophysics was to be appointed. (5) Editors would be paid honoraria (Governing Board Minutes, November 1970).

The structure of the publications program was now in the hands of Morgan and the Governing Board. Arthur Melton, Richard C. Atkinson, and Morgan agreed that 
with the increasing amount of scientific activity, the APA should not dominate the journal picture in experimental psychology, in part because there was talk about eliminating the APA's money-losing journals in experimental psychology. Furthermore, they felt that the Psychonomic Society had missed the boat as Academic Press started the Journal of Verbal Learning and Verbal Behavior, Cognitive Psychology, and Learning and Motivation. The latter journals were viewed as expensive, but profitable. In March, Morgan (1971b) proposed what would be the kernel of the new arrangement, when he suggested three new journals: Human Learning and Thinking, Animal Learning and Behavior, and Physiological Psychology. He wanted to add one journal per year, beginning in 1972. "It would, in brief, provide a cheaper outlet than Academic Press journals, and it would protect us all-contributors, subscribers, and editors-against what may or may not happen in the APA" (Morgan, 1971b).

At its November 1971 meeting, the Governing Board voted to have the Chairman appoint a committee to study the publications situation. The committee consisted of Melton (Chairman), Atkinson, William K. Estes, Harold W. Hake, and Delos D. Wickens. The Committee then made five recommendations:

First, it recommended that a permanent Publications Committee be established to deal with matters concerning publications. It would be a three-person committee with staggered 3-year terms.

Second, the Committee recommended the establishment of three new journals comparable to Perception \& Psychophysics. These would be Memory \& Cognition, Animal Learning \& Behavior, and Physiological Psychology. Each would publish reports of empirical research, integrative reviews, and theoretical developments and be formed as outgrowths of Psychonomic Science.

Third, the Committee recommended "the establishment of a journal for the publication of brief reports with the proposed title Bulletin of the Psychonomic Society." The new journal would provide for rapid publication of brief reports of up to 2,000 words, in the spirit of the original Psychonomic Science. Publication in the Bulle$t$ in would not preclude later publication of the same work as part of a larger article in an archival journal. The Committee proposed that the journal would automatically publish any member's articles as long as they conformed to journal style and were understandable. Nonmembers could submit articles if the papers were sponsored by a member.

Fourth, the Committee recommended the continued publication of Behavior Research Methods \& Instrumentation.

Finally, the Committee recommended the continued publication of monographs, but under the new title Psychonomic Monographs. With some misgivings that Morgan was proceeding too fast and that the Bulletin and monograph publication were unnecessary, the Board went along with the recommendation by an 11-1 vote.
The Committee's plan for the new journal structure was put into effect in January 1973, with the exception that no monographs have been published since 1972 and the Publications Committee was larger than had been envisioned. The three primary journals would be fully edited and, along with Perception \& Psychophysics, bound with glue and given stiff covers and backs to make them comparable to other leading journals. The six journals would remain intact for the next 20 years.

Following the recommendation of a joint meeting of the Membership Committee and ad hoc Publications Committee in Albuquerque, New Mexico, on April 4, 1974, the Publications Committee was established as a standing committee at the 1974 Governing Board meeting, with Melton, Atkinson, Hake, Gordon Bower, and Gregory Kimble as members and Morgan continuing in his role, now defined as Director of Publications. There would be a rotation in which a new member of the fiveperson committee would be appointed each year and the senior member of the Committee would automatically become its Chair.

Another matter that arose concerned the possibility of a blind review procedure in the Psychonomic Society journals. The matter was raised by John J. Furedy (1971), with the support of several other faculty members of the University of Toronto. The Governing Board rejected this proposal at its November 1971 meeting. Furedy then raised the issue at the business meetings of 1971 and 1972; Furedy's motions were defeated.

\section{The Death of Clifford T. Morgan and Its Aftermath}

In a draft memorandum to the Governing Board, Morgan (1971a) proudly noted how he had been able to recede from the journal management picture. He wrote:

As matters stand now, I could drop dead tomorrow and the journals would hardly show the difference. All of the work on the journals in the Publications Office is being done by paid personnel-personnel who have been carefully selected and developed and who are real crackerjacks.

On February 12, 1976, Clifford T. Morgan, age 60, died suddenly of a heart attack. This precipitated a crisis for the journal program that was greatly exacerbated by the tragic fact that the Managing Editor, his good friend Ann Sanford, had died just 11 days earlier, on February 1 . No one was prepared for the loss of the two people most knowledgeable about the publishing operation within so short a time. Even the ledger, which Morgan routinely took home, was missing.

In the day and a half following the memorial services for Morgan in Austin, there was an emergency meeting of members of the Publications Committee, joined by Melton, Thompson, and Janet Spence, chaired by Gregory Kimble (Spence, 1976). Consistent with Morgan's plan, two of his staff, Sharon Tarver and Anne Dossett, were appointed as Managing Editors. Melton, who had 
been on leave at the University of Texas at the time, agreed to spend several days a week at the Publication Office helping with the reorganization and was appointed Acting Director of Publications (Kimble, 1976; Spence, 1976).

The short-term problem solved, those assembled turned their attention to the long term. They decided that they needed an experienced psychologist to spend some time, as long as 15 months, in Austin developing solutions to the long-term problems of the publications program. As one of his many gifts to the society, Morgan had taken out a $\$ 45,500$ life insurance policy with the Society as the beneficiary. The group decided to spend the insurance money to bring in this "Executive Officer" (Spence, 1976) or "Royal Commissioner" (Kimble, 1976).

\section{The Ehrenfreund Year}

David Ehrenfreund, Chairman of the Department of Psychology at Southern Illinois University, agreed to fill the position for the term of August 15, 1976, until August 15,1977 . Ehrenfreund faced a number of critical problems. They illustrate the extent to which the Society, founded so as to avoid the nitty-gritty problems of the practical business world, had become enmeshed in it. For one, there was no insurance on the Austin operation. Ehrenfreund took out policies to cover losses or damage to equipment, etc., due to fire, flood, etc., and to cover costs of personal injury liability. Soon after the policy was in force, on Friday, December 10, 1976, there was a fire that destroyed some chemicals and paper, the collator, and about 18,000 sheets of Animal Learning \& Behavior (Ehrenfreund, 1976, 1995).

The bookkeeping system was modernized. The Society applied for the reduced postal rates to which educational and scientific institutions were entitled. Ehrenfreund got the approval of the Publications Committee to add advertisements to the journal. He also contracted for health and retirement insurance for the staff (Ehrenfreund, 1995).

The staff worked to ensure that journals were mailed on a date closer to that appearing on the covers. Part of this plan included the purchase of two new pieces of machinery; one that would automatically tie bundles of journals (which heretofore had been tied by hand) and an electrically operated, motor-driven paper cutter to trim the journals (which had been trimmed by hand with a giant paper cutter). Later a second printing press was purchased. The quality of figures in the journals was improved by standardizing the sizes that would be accepted and improving the production process. The format of the page with the Table of Contents was improved. The design of the covers was improved and each journal got its own color.

\section{Journal Credits and Funding}

With the Morgan financial support gone, several other steps were necessary in order to ensure financial stability for the journal program. Therefore, some important decisions were made at the business meeting of the Society on November 12, 1977. One imposed a special, one-time-only $\$ 10$ assessment to be levied on all members. This provided a cash reserve with which to handle the cash flow problem that was about to occur.

Second, the dues were raised from $\$ 5$ per year to $\$ 25$ annually, with the $\$ 20$ increase allocated to a journal credit. This would provide strong encouragement for members to subscribe to at least one of the Society's journals (Thompson, 1976). By 1994 the journal credit would be increased to $\$ 46$, with $\$ 16$ earmarked for the Psychonomic Bulletin \& Review.

There were some complaints about the increase and the number of nonrenewing members was higher than usual the following year. The estimate, as of the May 1978 meeting of the Publications Committee, was that the membership loss was nearly $30 \%$. On the other hand, individual subscriptions to the journals increased $50 \%$, compared with a $4 \%$ increase in institutional subscriptions.

\section{A PERIOD OF RELATIVE CALM AND STASIS}

By the end of the 1970s, the journal publishing program of the Psychonomic Society had now been shaped into its mature form. Morgan had founded the journals and given them to the Society. The 1973 structure had been adopted. The program had recovered from the loss of Clifford T. Morgan and Ann Sanford. Subscriptions were up, following the introduction of increased dues and the journal credit. There was still much to do as the new Publications Committee set about to manage an increasingly complex journal program. However, the changes that would occur over the next 15 years or so seem small in comparison with the events that shaped the program.

The Publications Committee continued to hold spring meetings in Austin and fall meetings in conjunction with the annual Society meeting as it continued to manage the journal program. Although some matters had to be referred to the Governing Board, the Publications Committee had broad authority to run the publishing program; indeed, members of this committee were largely responsible for it. A list of those serving on the committee, as best we have been able to reconstruct it, appears in Table 1. Many important issues had to be addressed as the times, and especially the technology, changed. However, this all occurred within a pattern that had been established previously.

The first problem was to work out an organizational chart so that there were clear lines of authority from the Publications Committee down to the individual staff. At its rather contentious April 1977 meeting, the Committee, contrary to Ehrenfreund's recommendation, agreed to try running the office with Anne Dossett and Sharon Tarver in charge, without a single Director. When it became apparent that the arrangement was not working ideally, the Publications Committee arranged for Judith Goggin to serve as Acting General Editorial Advisor in order to address the problem (Greeno, 1980); this appointment was later extended twice. An effective transition to a new structure was completed in 1983, when Ellen Woodard 
Table 1

Members of the Publications Committee

\begin{tabular}{cl}
\hline Year Added & \multicolumn{1}{c}{ Name } \\
\hline 1974 & Arthur W. Melton \\
1974 & Harold W. Hake \\
1974 & Richard Atkinson \\
1974 & Gordon H. Bower \\
1974 & Gregory A. Kimble \\
1976 & Endel Tulving \\
1976 & G. Robert Grice \\
1979 & James Greeno \\
1980 & Janet T. Spence \\
1981 & George Mandler \\
1982 & Lyle E. Bourne, Jr. \\
1983 & Walter Kintsch \\
1983 & Robert Rescorla \\
1984 & Robert G. Crowder \\
1985 & Richard M. Shiffrin \\
1986 & C. R. Gallistel \\
1987 & Donald Blough \\
1988 & Linda M. Bartoshuk \\
1989 & Anne M. Treisman \\
1989 & Alice F. Healy \\
1990 & Henry L. Roediger III \\
1991 & Elizabeth Loftus \\
1992 & Douglas L. Medin \\
1993 & Michael Domjan \\
1994 & Elizabeth D. Capaldi \\
1994 & Roberta L. Klatzky \\
1995 & James R. Pornerantz \\
1996 & Howard Egeth \\
\hline
\end{tabular}

Note-Members usually serve 5-year terms, with one new member per year.

was hired as the new Business Manager. She would become the key link between the Publications Committee and the Austin staff. At its June 1988 meeting, the Publications Committee decided to make Ellen Woodard Executive Director and Anne Dossett the sole Managing Editor. Woodard's title was changed to Director in 1993.

Part of the key to the successful operation of the Publications Office has been a line of very fine employees, most of whom cannot be mentioned. Surely, Anne Dossett and C. E. Wheeless were pivotal (End of an Era, 1993). Ellen Woodard, who had shepherded the office through some difficult times, resigned in 1995. She was replaced by Robert (Rob) Sanford, son of Fillmore and Ann Sanford.

The production of journals is done entirely in the Austin offices. These offices have been moved on several occasions. At its November 1986 meeting, the Publications Committee recommended to the Governing Board the purchase of its own property. The 3-year-old building at 1710 Fortview Road had over 5,000 square feet of space in an area zoned for commercial use. On March 16, 1987, the Board of Directors authorized purchase of the building at a price of $\$ 235,000$. The staff now had an adequate facility in which to work more efficiently and more comfortably.

Production is a complex process involving authors, editors, and the Austin staff. Delays anywhere in the chain could disrupt the process. Throughout the late 1970s and early 1980s, the Publications Committee addressed the problem of publication delays; the dates on journal covers did not correspond with the dates of publication. By November 1986, the staff could report that all had been caught up.

As the technology improved, the office worked to keep up. In the late 1980s, the Publications Office began experimenting with manuscripts submitted on computer diskettes; it would become the preferred mode. In recent years, the whole operation has seen increasing computerization, with a move to Macintosh desktop publishing. The office now has "four networked Macintosh Quadras, large grayscale and color monitors, a laser printer for proofs, an Agfa 9400 phototype imagesetter, and an Agfa 9000 RIP" (Huebner, 1995). Huebner provides additional details. In contrast to the advances in typesetting, however, the printing process is relatively unchanged, and the two presses that have printed many millions of journal pages were still in use in 1995, when one was replaced by a more elaborate model.

A program of stipends for Editors was initiated relatively early in the life of the Publications Committee. In 1977 , Editors were paid $\$ 3,000$ annually; each journal also received $\$ 3,000$ to spread among its Associate Editors on the condition that none receive more than $\$ 1,500$. The Editors' stipends now are $\$ 6,000$. A Psychonomic Editor's Manual was developed in 1982.

The Newsletter of the Psychonomic Society, which had first been published during the early days of the Society, was revived in 1992. This greatly improved communication between the Publications Committee and the membership at large.

\section{THE JOURNALS}

What all of this activity is about, of course, is the production of high-quality scientific journals. It is appropriate to examine them both in the aggregate and individually. During the period from 1973 to 1993, the Society basically published six journals: Animal Learning \& Behavior, Behavior Research Methods \& Instrumentation (later Behavior Research Methods, Instruments, \& Computers), the Bulletin of the Psychonomic Society, Memory \& Cognition, Perception \& Psychophysics, and Physiological Psychology (later Psychobiology).

Although the goal was to produce journals of equal quality, the journals were not equally successful in other respects. As indicated above, Psychonomic Science was wildly successful during its first few years. Perception $\&$ Psychophysics has been among the most successful of the journals in many respects, because it filled the right need at the right time with the right people behind it. Psychonomic Monograph Supplements, by contrast, was never a success. After the realignment of journals in 1973, the Bulletin of the Psychonomic Society never achieved the success of Psychonomic Science, perhaps because so much was drawn from it to the three new specialty journals. Of those, Memory \& Cognition has flourished to a 
greater extent than have the two journals dealing primarily with nonhuman subjects.

Data for the number of subscriptions per year are presented in Figure 1. For the journals shown (the Psychonomic Bulletin \& Review is not shown; begun in 1994, it goes to all members), Memory \& Cognition has been the circulation leader in every year since its inception. Perception \& Psychophysics is a clear runner-up, with the remaining four journals tightly bunched over the last half of their existence, but with different histories before that and a slight downward trajectory in recent years.

Clifford Morgan observed that submissions and subscriptions often are correlated. The number of pages printed per year is presented in Figure 2. The number of pages in Psychonomic Science nearly quadrupled from the founding in 1964 until 1967, when there was a peak at 1,614 as the journal moved from a single volume to two, then three, and finally four volumes beginning in 1968 . Perception \& Psychophysics shows a steady growth from its founding through to the present. The 1973 drop in Psychonomic Science is artifactual; it reflects the movement of material into four new journals and the shift to the Bulletin of the Psychonomic Society. The other journals show somewhat smoother patterns, with Memory \& Cognition breaking out from the pack in recent years. The most problematic journal has been Psychobiology, which has shown a serious problem with submissions and comprised just two issues with 152 pages in 1986 .

An indication of the perception of the journals can be seen in that at the November 1985 Publications Committee meeting, the Committee was referring to "the three larger (\& stronger)" versus "the smaller ( \& weaker) journals," although at this point the circulations of the four smaller journals were tightly bunched. By my count, the journal program published over 107,000 pages of journals between 1964 and 1994.

The prices to individuals of the journals are shown in Figure 3. As might be expected, as costs of almost everything have risen during this period, there has been a steady increase in the costs of the journals. There was a bit of a flattening in the late 1980s. Prices are correlated with the number of pages published (see Figure 2). Thus, Perception \& Psychophysics, the largest journal, has the highest subscription price. Overall, costs have been held well below those of many other comparable journals.

Institutional subscriptions generally were approximately twice as expensive as those for individuals. Student subscriptions have been offered at about $1 / 2$ to $2 / 3$ the cost to other individuals.

Though a highly imperfect measure, one way to assess the impact of journals is to use citation analyses. Selected data are presented in Table 2. Available data for Psychonomic Society journals are reported, along with some comparison data from other journals. The results present a somewhat different picture from that presented from the other data above. Among the Psychonomic Society journals, the highest scoring on the "impact factor" is Psychobiology; Behavior Research Methods, Instruments, \& Computers scores lowest. The Psychonomic journals fall generally below comparable APA journals, but above many other journals in the field.

\section{Psychonomic Science}

The origins and early years of Psychonomic Science have been discussed above, since its origins are the ori-

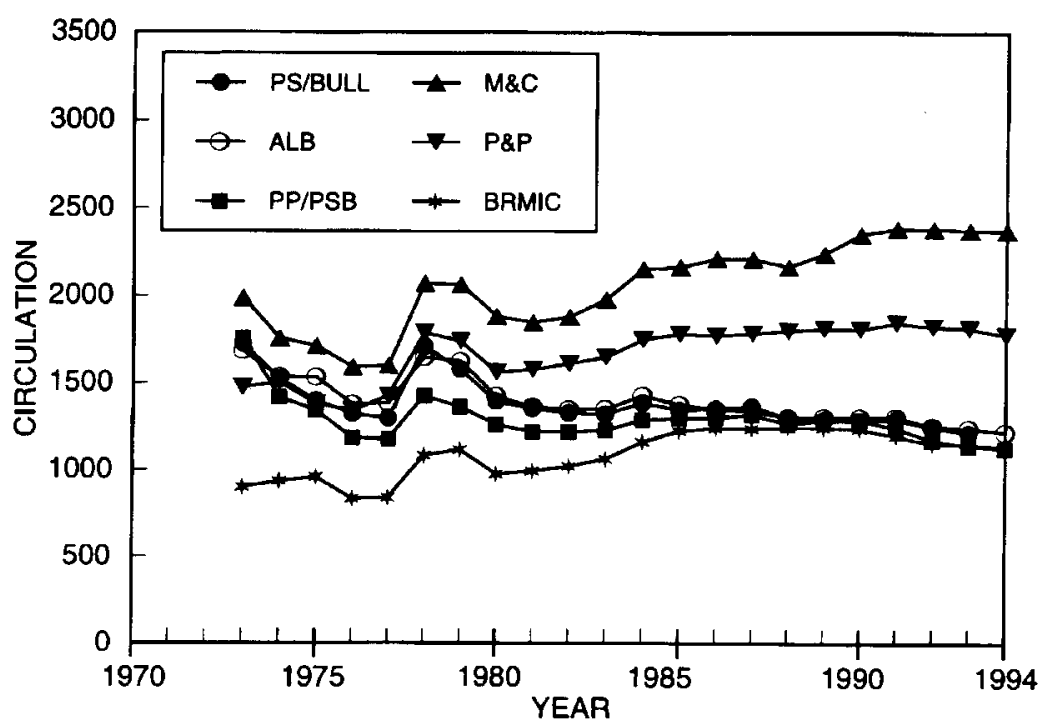

Figure 1. Number of subscriptions per year for six major journals of the Psychonomic Society. PS/BULL, Psychonomic Science/Bulletin of the Psychonomic Society; ALB, Animal Learning \& Behavior; PP/PSB, Physiological Psychology/Psychobiology; M\&C, Memory \& Cognition; P\&P, Perception \& Psychophysics; BRMIC, Behavior Research Methods, Instruments, \& Computers. 


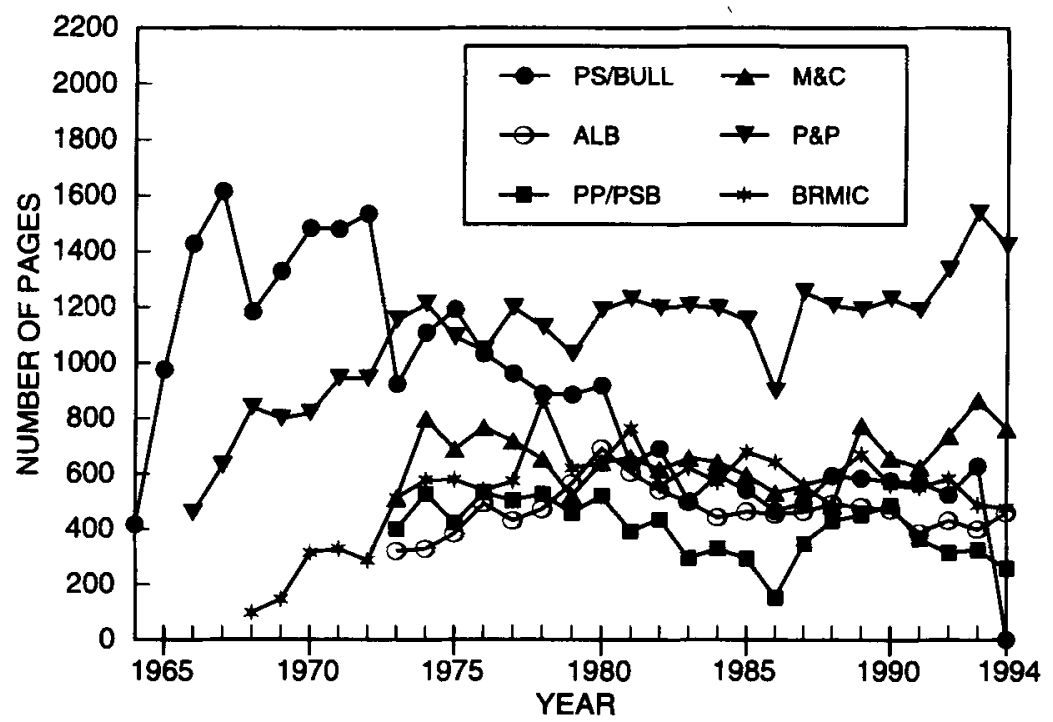

Figure 2. Number of pages published per year for six major journals of the Psychonomic Society. PS/BULL, Psychonomic Science/Bulletin of the Psychonomic Society; ALB, Animal Learning \& Behavior; PP/PSB, Physiological Psychology/Psychobiology; M\&C, Memory \& Cognition; P\&P, Perception \& Psychophysics; BRMIC, Behavior Research Methods, Instruments, \& Computers.

gins of the entire Psychonomic Society publishing program. As is apparent from Figure 2, Psychonomic Science was an immediate success and went from 1 to 4 volumes per year in just 5 years.

The issue of standards and the degree of refereeing arose from time to time. Lists of reviewers were published each year and included many of the most respected names in the field. The list for Volume $19(1970)$ included 102 names. Morgan (1970) noted that, in the interest of rapid and brief publication, he had very loose editorial standards. In the 2 years before his report, however, he had had every article not authored by a Society member $(70 \%$ of the articles) refereed by at least one reviewer. About $25 \%$ of those were rejected and many of the remainder were sent back for revision. He was now preparing to make the journal fully reviewed.

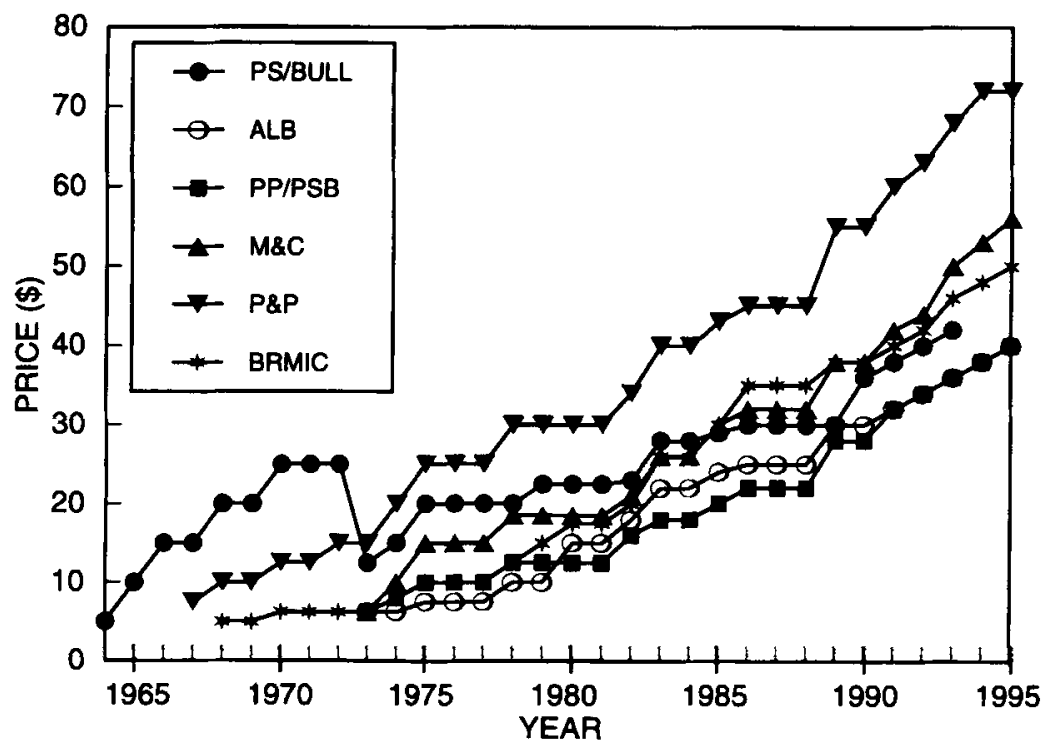

Figure 3. Subscription price to individuals of six major journals of the Psychonomic Society. PS/BULL, Psychonomic Science/Bulletin of the Psychonomic Society; ALB, Animal Learning \& Behavior; PP/PSB, Physiological Psychology/Psychobiology; M\&C, Memory \& Cognition; P\&P, Perception \& Psychophysics; BRMIC, Behavior Research Methods, Instruments, \& Computers. 
Table 2

Data for Psychonomic Society Journals

and Assorted Other Journals From the 1993

Science Citation Index Journal Citation Reports and

Social Sciences Citation Index Journal Citation Reports

\begin{tabular}{|c|c|c|c|c|}
\hline Journal & $\begin{array}{l}\text { No. } \\
\text { Citations }\end{array}$ & $\begin{array}{l}\text { Impact } \\
\text { Factor }\end{array}$ & $\begin{array}{l}\text { Immediacy } \\
\text { Index }\end{array}$ & $\begin{array}{c}\text { No. Source } \\
\text { Items } \\
\end{array}$ \\
\hline \multicolumn{5}{|c|}{ Psychonomic Society Journals } \\
\hline Psychobiology & 622 & 1.791 & 0.150 & 40 \\
\hline Animal Learning \& Behavior & 1,037 & 1.416 & 0.213 & 47 \\
\hline Memory \& Cognition & 2,173 & 1.331 & 0.358 & 81 \\
\hline Perception \& Psychophysics & 3,635 & 1.278 & 0.171 & 146 \\
\hline $\begin{array}{r}\text { Behavior Research Methods, } \\
\text { Instruments, \& Computers }\end{array}$ & 457 & 0.429 & 0.000 & 74 \\
\hline \multicolumn{5}{|c|}{ Other Publishers } \\
\hline Nature & 226,827 & 22.326 & 5.309 & 990 \\
\hline Psychological Review & 7,193 & 6.500 & 0.865 & 37 \\
\hline \multicolumn{5}{|l|}{ Journal of Experimental Psychology: } \\
\hline General & 1,902 & 2.870 & 0.452 & 31 \\
\hline Human Perception \& Performance & 3,502 & 2.327 & 0.364 & 77 \\
\hline Learning, Memory, \& Cognition & 2,727 & 2.694 & 0.635 & 96 \\
\hline Animal Behavior Processes & 1,157 & 2.560 & 0.452 & 31 \\
\hline Behavioral \& Neural Biology & 1,466 & 1.817 & 0.458 & 72 \\
\hline Animal Behaviour & 6,010 & 1.594 & 0.418 & 280 \\
\hline $\begin{array}{c}\text { Journal of the Experimental } \\
\text { Analysis of Behavior }\end{array}$ & 2,213 & 1.551 & 0.354 & 79 \\
\hline Journal of Comparative Psychology & 748 & 1.404 & 0.238 & 42 \\
\hline Perceptual \& Motor Skills & 2,342 & 0.262 & 0.134 & 486 \\
\hline
\end{tabular}

Note-Impact factor $=$ the number of citations per citable article. Immediacy index $=\mathrm{a}$ measure of how quickly the average article is cited. Data for Bulletin of the Psychonomic Society and Psychonomic Bulletin \& Review are not available.

Morgan had been the sole Editor during the first years of the journal. Beginning in 1971, several editors handled sections of the journal. These editors, along with their areas of expertise, were Abram Amsel (Animal Learning and Behavior) and Richard F. Thompson (Physiological Psychology), who began editing the Section on Animal and Physiological Psychology, and George E. Briggs (Perception, Performance, and Experimental Social Psychology) and Rudolph W. Schulz (Memory, Learning, and Thinking), who handled the Section on Human Experimental Psychology (see Table 3).

In their inaugural editorial, the new editors immediately made it clear that they were taking charge and were concerned with quality: "In assuming direct charge of the publication of Psychonomic Science, the membership of the Psychonomic Society has indicated that it wishes to have a journal of very high quality devoted to the prompt publication of brief articles" (Amsel, Briggs, Schulz, \& Thompson, 1971). The maximum length of articles was now 3,000 words. The new editors cautioned against the submission of "pilot studies," replications of or slight variations on previous work, and papers with nonsignificant differences.

The new editors signaled the arrival of a new standard, causing Morgan some alarm:

I knew that when I turned over the editorship to you fellows, the rejection rate on manuscripts would go up, but I had no idea that it would be so precipitous. My rate was running $1 / 4$ to $1 / 3$, but your collective rate appears to ex- ceed $3 / 4$. Consequently, we have logged in as accepted by you less than a dozen manuscripts in the last six weeks. Previously, we would log nearly 100 in the same period of time. (Morgan, 1971c)

Morgan went on to explain the problems that this could cause for the production staff and process in Austin. As a result, he was cutting the number of pages per issue, starting each article on a new page rather than combining them, and trying to drum up new manuscripts. Most significantly, he added a new feature, citations of current literature in experimental psychology.

Psychonomic Science, under the four-editor arrangement, lasted just 2 years before undergoing the four-way split described above.

\section{Bulletin of the Psychonomic Society}

Although Psychonomic Science ceased to exist, being replaced by four spinoffs, the one that most closely resembled its progenitor was the Bulletin of the Psychonomic Society. Morgan (1973) explained that the new journal combined a new concept with an old one. "The new concept is that members of the Psychonomic Society, being carefully selected for their contributions to experimental psychology, are competent to be their own editors" (Morgan, 1973, p. 1). This was the same principle that was used in accepting papers for presentation at the annual meetings. The old concept was that of brief and rapid publication, which was applied in Psychonomic Science from the start. The limits on length were 
Table 3

Editors of Journals of the Psychonomic Society

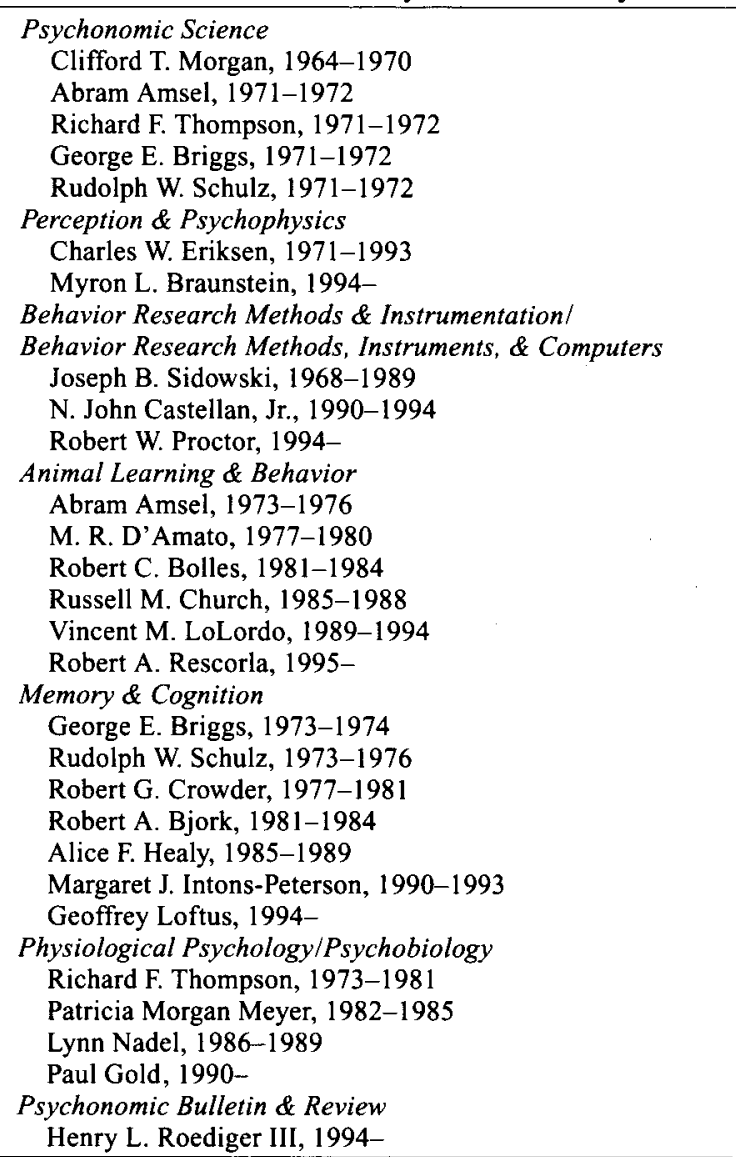

to be eased somewhat, but articles were to be no longer than two printed pages. In essence, the Bulletin would publish articles by its members or sponsored by its members without further review. Though not requiring the purchase of reprints, Morgan tried to shame authors into purchasing them, noting that "an author who takes valuable publication space ought to want to buy some reprints" (Morgan, 1973, p. 1). He had to finance the journal operation!

There was an ebb and flow of format for the journal as the number of submissions rose and fell, with criteria being tightened when submissions were many and loosened when they were few. A change in policy eliminated the practice of accepting sponsored articles effective January 1,1977 ; it was reinstated in 1983. Beginning with Volume 21 in 1983, the journal became bimonthly with just one volume per year; papers could be up to four pages in length.

The Bulletin was never as successful as Psychonomic Science had been; concerns were raised about the demand for the journal and the quality of its contents. The question of the continuation of the Bulletin was raised from time to time; it was discussed repeatedly during the 1980s. Discussion of the Bulletin at the November 1991 meeting was lively; one member repeatedly referred to it as a "junk journal." Finally, the decision was made to terminate the journal and replace it with the Psychonomic Bulletin \& Review. It was announced that "The Society's Publications Committee has decided that its original purpose-that of providing an outlet for quick, brief, unrefereed articles in experimental psychology at a time when publishing lags were generally very long-had been fulfilled and is no longer needed" (Bulletin, 1993, p. 168). The staff would receive manuscripts to fill the remaining numbers in 1993 and then cut off submissions.

In closing out the journal, Medin (1993) reviewed some highlights from its history and some of the more influential articles that had appeared in Psychonomic Science and the Bulletin of the Psychonomic Society. He noted that "this editorial is less about the demise of a journal than it is about a step in its evolution" (p. 501).

\section{Psychonomic Monograph Supplements}

Psychonomic Monograph Supplements was initiated in 1965 because Morgan wanted to provide an outlet for the publication of longer articles. Although the journal attracted articles from some fine authors, it was never a success, and it folded after four volumes with 2 years per volume, having comprised a total of 66 articles. Morgan tried to keep it alive in 1972 under the title of Psychonomic Monographs, but no articles were published.

\section{Perception \& Psychophysics}

Perception \& Psychophysics has been arguably the most successful of the Psychonomic Society journals, at least with respect to size. It was started with an Editorial Board of leading scientists in the field at a time when a journal in the area was badly needed. From its inception in 1966 through 1970, editorial chores were performed by the Board under Morgan's watchful eye. Charles W. Eriksen assumed the editorship in 1971 and retained it through 1993, the longest tenure of any Psychonomic editor. Myron L. Braunstein has held the position since Eriksen's retirement. A set of recollections of Eriksen was published in the journal (Kramer et al., 1994).

Morgan's (1966) opening editorial was discussed above. Eriksen did not publish an opening editorial. In his opening editorial, Braunstein (1994) noted the past success of the journal and his goal of continuing to move the journal ahead.

In 1976 the journal announced a new section, "Notes and Comment," that would include reader comments on published articles, and informal reports of recent data (see Perception \& Psychophysics, 1976, p. 471). Eriksen (1978) affirmed the importance of replications and the place for negative results in the journal. A special issue on "The Understanding of Melody and Rhythm" was edited by W. Jay Dowling and Edward C. Carterette in 1987.

Overall, Perception \& Psychophysics has been a relatively "quiet" journal with relatively few frills and an emphasis on the publication of data-and it has been a great success. 


\section{Behavior Research Methods \& Instrumentation/ Behavior Research Methods, Instruments, \& Computers}

Behavior Research Methods \& Instrumentation began publication in 1968 under the editorship of Joseph B. Sidowski. The intent was to "publish articles covering experimental methods and designs, instrumentation and laboratory techniques, and computer technology" (Sidowski, 1968, p. 1).

Just two issues totaling 98 pages were published the first year, but the journal then grew. The rejection rate consistently averaged about 50\% (Sidowski, 1989).

Sidowski $(1989,1995)$ reflected on the origins and development of the journal. The idea for the journal originated with a book, Experimental Methods and Instrumentation in Psychology (Sidowski, 1966). Following publication of the book, a number of people asked him about a journal because of the need for a continuous flow of information about new methods. Sidowski contacted Morgan at the suggestion of Richard Atkinson, and the journal developed from there (Sidowski, 1995). Sidowski noted that 3 of the original 10 consulting editors had predicted that the journal would be a failure. Computer methodology was a part of the journal from the start, but the word computers was added to the title to make it $B e$ havior Research Methods, Instruments, \& Computers in 1984. The delay was due primarily to the belief that computers were research instruments and that adding the word computers was therefore unnecessary.

A section on computer "Program Abstracts/Algorithms" was added in 1973, and Steven G. Vandenberg joined the journal as a consulting editor for this section the next year. The special sections and issues that were published are cited by Sidowski (1989); they included such topics as Computer-Based Tachistiscopes; Biofeedback Instrumentation; Computer Technology and Methodology in Clinical Psychology, Psychiatry, and Behavioral Medicine; and Microprocessors and Microcomputers. An index to computer-related articles was published in 1987. A book review section was added in 1989.

A major feature of the journal since 1974 has been the annual publication of the Proceedings of the National Conference on the Use of On-Line Computers in Psychology (now the Society for Computers in Psychology). The Society for Computers in Psychology was an outgrowth of Psychonomic Society activity (Sidowski, 1990). These proceedings have been a major influence and an important part of the journal.

Despite its many accomplishments, and especially the annual Computer Society issue, the journal did have its problems from time to time. It had always had the lowest number of subscribers of any of the journals and was regarded as a major money loser. On several occasions, the Publications Committee has considered abandoning the journal, but it has survived thus far.

Joseph Sidowski retired as Editor in 1989, the only other Psychonomic editor with a tenure comparable to that of Eriksen. He was succeeded by N. John Castellan, Jr. Castellan (1990) reflected on changes in the field as the instrumentation continued to become more sophisticated and stressed the role of Behavior Research Methods, Instruments, \& Computers in helping psychologists to utilize developing technologies to meet specific needs.

N. John Castellan, Jr., died on December 21, 1993, at the age of 54. A memorial tribute was published in the journal (Intons-Peterson, 1994), and an issue was dedicated to his memory (Aaronson \& Lehman, 1994). He was succeeded as Editor by Robert W. Proctor, who looked forward to a bright future for the journal (Proctor, 1994).

\section{Animal Learning \& Behavior}

Animal Learning \& Behavior was one of the four journals that "metamorphosed from its semiautonomous existence as one of four parts of Psychonomic Science" (Amsel, 1973) in 1973. Amsel (1995) recalled that the committee to reformulate the journals met in Austin and Amsel invited the committee members out for cocktails at his home after the meeting. At that point, there was to be just one journal to cover physiological psychology and animal learning. He suggested that two journals were needed and, when asked, produced the name Animal Learning \& Behavior on the spot. He wound up as the Editor and reflected, in a jocular manner, that the moral was that it is a good idea to invite people to your home for drinks. As a leader in his field, he might well have been invited to be Editor anyway.

Amsel enlisted 13 Associate Editors, each of whom would also serve as action editors. He encouraged theoretical contributions, comments on articles, and sound research. He cautioned, however, that

immaculate technique, design, and analysis are not sufficient grounds for publication. Authors should tell us in simple, succinct English why their studies were carried out, what news is provided by the results, and how they relate to a larger body of knowledge. (Amsel, 1973, p. 1)

Although some may regard such a statement as trite, it is a succinct statement of principles that are too often ignored.

Significantly, Amsel emphasized that Animal Learning \& Behavior was not to be a specialty journal. Rather, it was a place that provided opportunity for communication among those interested in different approaches, including, among others, Pavlovian conditioning, other paradigms for learning and motivation, animal development, and animal behavior.

M. R. D'Amato assumed the editorship in 1977 . He pledged to continue Amsel's policies, including a dispersal of editorial effort among Associate Editors, and he encouraged empirical reports, theoretical papers, and critical reviews (D'Amato, 1977). The next year D'Amato added a "Notes and Comment" section. When Robert C. Bolles succeeded D'Amato in 1981, he praised the "marvelous diversity of our authors" and noted that "we relish this diversity" (Bolles, 1981, p. 1). In assuming the 
editorship in 1985, Russell M. Church again praised the breadth of coverage and noted as his goals that "a journal can facilitate the development and dissemination of important new ideas and improve the quality of support for old ideas" (Church, 1985, p. 1). As he assumed the editorship, Robert A. Rescorla (1995) sought more multiexperiment articles and integrated summaries of the work in single laboratories.

With time, the diversity that had characterized the journal at its founding became less and less apparent, so that it became largely a journal of animal learning and memory (Dewsbury, 1991). Although a journal of high quality, it was no longer noted for great diversity.

\section{Memory \& Cognition}

Memory \& Cognition also emerged from Psychonomic Science in 1973, under the editorship of George E. Briggs and Rudolph W. Schulz, who had served in similar positions for the predecessor journal. They noted that the journal would be distinctive in that it would contain not only the results of empirical research, but also scholarly reviews and theoretical articles (Briggs \& Schulz, 1973). George Briggs died on December 19, 1974, at the age of 48, leaving Schulz the sole editor; Irving Biederman was brought in as the sole Associate Editor in 1975. Schulz was succeeded by Robert G. Crowder, Robert A. Bjork, Alice F. Healy, Margaret J. Intons-Peterson, and Geoffrey Loftus (see Table 3).

Most new editors praised the work of their predecessors and promised few changes (Bjork, 1982; Crowder, 1977; Healy, 1986). An exception was Loftus (1993), who promised more of a departure from tradition.

Several issues recur through the inaugural editorials of the seven psychologists who have edited the journal. Briggs and Schulz (1973) noted that "it is expected that most manuscripts will represent major data-collection efforts by the authors either through the report of a series of interrelated studies or through a single but comprehensive experimental design" (p. 1). Crowder (1977) favored the multiexperiment article: "by far the most usual agency for an important contribution... is an article summarizing an integrated program of several experiments" (p. 1). Bjork (1982) felt that the trend toward multiexperiment papers had gone too far and that the policy encouraged publication of both "pilot studies" and "insubstantial follow-up experiments." He proposed that "given a well-defined experimental question, a single experiment of sufficient power to answer that question may sometimes suffice" (p. 1). Healy (1986) appeared equally sympathetic to single- and multiexperiment articles. Loftus (1993) moved back toward Bjork, arguing that the "high-quality briefer manuscripts are underrated" (p. 1).

The editors tried to delimit the range of areas covered by the journal so as to not spread it too thin. Crowder (1977) was sympathetic to research at the boundaries of the field of memory and cognition, but he questioned how effectively the staff could deal with articles in such borderland areas as experimental social psychology, per- ception, and conditioning. Healy (1986) tried to delimit the core area of coverage as including "memory, cognition, and information processing, including such topics as reading, speech perception, pattern recognition, sensory memory, attention, learning, forgetting, concept formation, knowledge retrieval, psycholinguistics, text processing, problem solving, reasoning, thinking, judgment, and decision making" (p. 1).

The editors of Memory \& Cognition tended to be more outspoken on matters of experimental design than did those of the other journals. Healy (1986) cautioned against comparisons across different experiments, reports of inferential statistics without giving measures of central tendency and variability, inadequate checking of references, and inconsistent use of APA style. Intons-Peterson (1990) tried to use her educational experiences to demonstrate the value of "hard-hitting, thought-provoking, challenging reviews" (p. 1).

Loftus (1993) asked that authors submitting to Memory $\&$ Cognition articles that had been rejected elsewhere provide copies of the relevant correspondence. He also asked that authors prepare for distribution on request computer files of raw data in an ASCII format. Loftus's strongest departure was a move away from the longcherished mainstay of reliance on hypothesis testing in experimental articles.

Healy (1986) noted that the rejection rate for Memory \& Cognition was running between $70 \%$ and $80 \%$. IntonsPeterson (1990) set it at about $80 \%$.

\section{Physiological Psychology/Psychobiology}

The third of the fundamentally new journals to emerge from Psychonomic Science was Physiological Psychology; this name was changed to Psychobiology in 1987. In his inaugural editorial, Richard F. Thompson (1973) noted the importance of Clifford T. Morgan not only to the journals but also to the field of physiological psychology itself; he dedicated the first issue to Morgan. Under Thompson, "Physiological Psychology will encompass studies in which physiological manipulations and/or measures are employed as independent or dependent variables, where the work is relevant to psychological phenomena" (p. 1).

When Patricia Morgan Meyer (1982) assumed the editorship, she dedicated her inaugural issue to both Morgan and Thompson. She quoted Morgan's textbook of 40 years earlier in treating the subject of physiological psychology as "the study of the physiological mechanisms of behavior" (p. 1). Meyer also introduced a Short Communication section.

Lynn Nadel, who succeeded Meyer in 1986, was among the most outspoken of editors. He was the only editor to publish editorials jointly authored with his Associate Editors. Nadel, Barnes, Gallagher, Kolb, and Willner (1986) pointed to new developments in neuroanatomical, neurophysiological, and behavioral techniques and pointed to them as what attract may young scientists to the field. However, they bemoaned the loss of perspective for the 
" "whole' animal" in many of them. Reductive strategies had served neuroscience well, and most neuroscientists assumed that they would do the same for problems of behavior. Nadel et al. believed that "the long-awaited and exciting time is now upon us" (p. 1), but worried that "physiological psychologists, or psychobiologists, or biopsychologists, or neurobiologists, or, most commonly, neuroscientists, have generally lost the habit of 'thinking large,' or seeing the proverbial 'big picture'" (p. 1). They encouraged authors to think large again. Nadel et al. anticipated that half of the journal space would be for provocative articles and other material besides empirical reports. The new editors promised to uphold high standards of animal welfare in published articles and to solicit several articles focusing on issues of animal welfare. When he assumed the editorship in 1990, Paul Gold (1990) repeated the call for breadth.

A major problem for the Psychonomic Society was that many physiological psychologists found their home in a place other than the Psychonomic Society, particularly in the Society for Neuroscience. This led to problems regarding the numbers of both submissions and subscriptions. Many of those publishing in the journal were not members of the society that was subsidizing it. The Publications Committee repeatedly addressed the problem with successive editors.

Editor Patricia Meyer took a number of steps, including the addition of invited articles. Matters did not get better, however. Nadel (1988) was able to report that the submission rate was up about $35 \%$, that the quality was up, and that the journal was coming out on time. However, he lamented the small number of book reviews, conference reports, and other more integrative submissions. He wanted the readers to take a more active role in the growth of the journal.

In 1991, the Publications Committee appointed an ad hoc committee to provide advice regarding the future of Psychobiology. The Society was losing $\$ 35$ for each page published in Psychobiology (Roediger, 1991). The last three editors were not even members of the Society, nor were two thirds of the consulting editors. With Medin's committee's report in hand, the Publications Committee decided to continue the journal and to redouble its efforts to strengthen it (Medin, 1992; Roediger, 1992).

\section{Psychonomic Bulletin \& Review}

The newest Psychonomic Society journal is the Psychonomic Bulletin \& Review, which began publication in 1994. The new journal was created to replace the $B u l$ letin of the Psychonomic Society, regarded as filled with papers of low quality, with a journal that would be fully refereed and comparable to the best in the field. It would be mainly a vehicle for publishing theoretical and review papers because the other Psychonomic journals emphasized empirical reports. In his lead editorial, Henry L. Roediger III (1994) listed four kinds of articles that would be encouraged: theoretical articles, review articles, opinion articles, and brief reports. A section of Current Contents of Psychonomic Society journals was introduced.
Initially, the journal was to start with a normal individual subscription cost of $\$ 40$, with a price of $\$ 25$ to members who subscribed to at least one other Psychonomic Society journal. At the November 1993 Publications Committee meeting, however, it was recommended that the Psychonomic Bulletin \& Review should be sent to all members with an increase of $\$ 16$ in the mandatory journal credit, which was treated as if not part of the dues; the Governing Board approved the proposal. This is now the only journal received by all members of the Psychonomic Society.

\section{CONCLUSION}

From its tentative beginnings, the publications program of the Psychonomic Society has grown into a solid operation with six authoritative journals in the field of experimental psychology. This program has been developed as the result of the collective judgment and efforts of many individuals, both in the Psychonomic Society and on the Austin staff. All indicators point to a period of continued stability for the foreseeable future.

\section{REFERENCES ${ }^{2}$}

Aaronson, D., \& Lehman, R. S. (1994). Dedication to N. John Castellan, Jr. (1939-1993). Behavior Research Methods, Instruments, \& Computers, 26, 77-78.

Amsel, A. (1973). Editorial. Animal Learning \& Behavior, 1, 1-2.

Amsel, A. (1995, March 7). [Interview with Donald A. Dewsbury, Austin, TX].

Amsel, A., Briggs, G. E., Schulz, R. W., \& Thompson, R. F. (1971). Editorial. Psychonomic Science, 24, 1.

BeECroft, R. S. (1966). Classical conditioning. Goleta, CA: Psychonomic Press.

BJORK, R. A. (1982). Editorial: Some observations on a year's worth of manuscripts. Memory \& Cognition, 10, 1 .

Board of ScIENTIFIC AfFairs (1959). Technical communication in psychology: A statement of the problem. American Psychologist, 14, 267-271.

Bolles, R. C. (1981). Editorial. Animal Learning \& Behavior, 9, 1. Braunstein, M. L. (1994). Editorial. Perception \& Psychophysics, 55, 9-10.

Briggs, G. E., \& Schulz, R. W. (1973). Editorial. Memory \& Cognition, 1,1 .

Castellan, N. J., JR. (1990). Editorial. Behavior Research Methods, Instruments, \& Computers, 22, 1-2.

Church, R. M. (1985). Editorial. Animal Learning \& Behavior, 13, 1. Crowder, R. C. (1977). Editor's comment. Memory \& Cognition, 5, 1.

D'Aмato, M. R. (1977). Editor's comment. Animal Learning \& Behavior, $5,1$.

Dewsbury, D. A. (1991). Animal Learning (\& Behavior?). Bulletin of the Psychonomic Society, 29, 57-58.

Dewsbury, D. A., \& Bolles, R. C. (1995). The founding of the Psychonomic Society. Psychonomic Bulletin \& Review, 2, 216-233.

Dr. Fillmore Sanford, 53, dies; Psychologist fought quacks. (1967, August 7) New York Times, p. 29.

DossetT, A. (1995, March 6). [Interview with Donald A. Dewsbury]. Psychonomic Society Archives.

Ehrenfreund, D. (1976, December 14). [Letter to Harold W. Hake] Psychonomic Society Archives.

Ehrenfreund, D. (1977). Chronology and history of the Psychonomic Society. Psychonomic Society Archives.

Ehrenfreund, D. (1995, January 23). [Letter to Donald A. Dewsbury]. Psychonomic Society Archives.

End of an era: Dossett and Wheeless, Publications Office mainstays, to retire. (1993, fall). Newsletter of the Psychonomic Society, pp. 1, 7. 
ERIKSEN, C. W. (1978). Announcements from the editor. Perception \& Psychophysics, 24, 1.

Furedy, J. J. (1971, February 9). [Letter to Arthur W. Melton] (Psychonomic Society Archives, Box 488.1). Akron, $\mathrm{OH}$ : University of Akron, Archives of the History of American Psychology.

Garner, W. R. (1976). Clifford Thomas Morgan: Psychonomic Society's first chairman. Bulletin of the Psychonomic Society, 8, 409415.

Geldard, F. A. (Ed.) (1973). Conference on cutaneous communication systems and devices. Austin, TX: Psychonomic Society.

GoLD, P. E. (1990). Editorial. Psychobiology, 18, 1

Graham, C. H. (1960, June 24). Memorandum to the Chairman and members of the executive committee, Psychonomics [sic] Society; the secretary of the society (Psychonomic Society Archives, Box 488.1, Folder 9). Akron, $\mathrm{OH}$ : University of Akron, Archives of the History of American Psychology.

Greeno, J. (1980, December 16). [Letter to Anne Dossett and Sharon Tarver]. Psychonomic Society Archives.

HeAly, A. F. (1986). Editor's comments. Memory \& Cognition, 14, 1.

Hearst, E., \& Jenkins, H. M. (1974). Sign-tracking: The stimulusreinforcer relation and directed action. Austin, TX: Psychonomic Society.

HuEbNER, M. (1995, spring). Publications Office update. Newsletter of the Psychonomic Society, p. 4.

Intons-Peterson, M. J. (1990). Editorial. Memory \& Cognition, 18, $1-2$.

Intons-Peterson, M. J. (1994). N. John Castellan, Jr.: In Memoriam. Behavior Research Methods, Instruments, \& Computers, 26, 1-3.

KIMBLE, G. A. (1976). Psychonomic Society: Emergency meeting of the Governing Board (Psychonomic Society Archives, Box 488.1). Akron, $\mathrm{OH}$ : University of Akron, Archives of the History of American Psychology.

Kramer, A., Coles, M., Eriksen, B., Garner, W., hoffman, J., \& LAPPIN, J. (1994). Charles Eriksen: Past, present, and future. Perception \& Psychophysics, 55, 1-8.

Lindzey, G., Winston, H. D., \& WhitNey, G. D. (1964). Defecation in stressful and non-stressful situations. Psychonomic Science, 1, 3-4.

Loftus, G. R. (1993). Editorial comment. Memory \& Cognition, 21, $1-3$.

Medin, D. L. (1992, fall). Review of Psychobiology. Newsletter of the Psychonomic Society, p. 6.

Medin, D. L. (1993). Editorial. Bulletin of the Psychonomic Society, 31, 501-502.

Melton, A. W. (1976). [Untitled tribute to C. T. Morgan]. Bulletin of the Psychonomic Society, 7, 233.

Meyer, P. M. (1982). Editorial. Physiological Psychology, 10, 1.

Morgan, C. T. (1963, October 25). [Letter to Donald B. Lindsley] Psychonomic Society Archives.

Morgan, C. T. (1964a). Editorial. Psychonomic Science, 1, 1-2.

Morgan, C. T. (1964b). Editorial notes. Psychonomic Science, 1, 102.

[Morgan, C. T.] (1964c). Editorial notes. Psychonomic Science, 1, viii.

[Morgan, C. T.] (1965). Editorial note. Psychonomic Science, 2, 34.

Morgan, C. T. (1966). Editorial. Perception \& Psychophysics, 1, 1

Morgan, C. T. (1967, May 2). [Letter and proposal to Judson S Brown]. Psychonomic Society Archives [reprinted by Ehrenfreund, 1977].

Morgan, C. T. (1968). Report of Editor-in-Chief. Psychonomic Society Archives.

Morgan, C. T. (undated [ca. 1970]). [Memorandum to the Publications Committee, Psychonomic Society]. Psychonomic Society Archives.

MoRGAN, C. T. (1970, October 13). [Memorandum to the Governing Board] (Psychonomic Society Archives, Box 642). Akron, OH: University of Akron, Archives of the History of American Psychology.

Morgan, C. T. (1971a, undated). [Draft memorandum to the Publications Committee, Psychonomic Society]. Psychonomic Society Archives.

Morgan, C. T. (1971b, March 28). [Memorandum to the Governing Board] (Psychonomic Society Archives, Box 490). Akron, OH:
University of Akron, Archives of the History of American Psychology.

Morgan, C. T. (1971c, June 21). [Memorandum to the Editors, Psychonomic Science] (Psychonomic Society Archives, Box 490). Akron, $\mathrm{OH}$ : University of Akron, Archives of the History of American Psychology.

Morgan, C. T. (1973). Editorial. Bulletin of the Psychonomic Society, 1,1 .

Morgan, M. (1995, March 8). [Interview with Donald A. Dewsbury, Austin, TX].

Morgan, P. (undated [1995, March]). [Letter to Donald A. Dewsbury]. Psychonomic Society Archives.

NADEL, L. (1988). Editorial. Psychobiology, 16, 1-2.

Nadel, L., Barnes, C. A., Gallagher, M., Kolb, B., \& Willner, J (1986). Editorial. Physiological Psychology, 14, 1-4.

Phinney, R. L. (1970, June 2). [Letter to Psychonomic Journals, Inc] Psychonomic Society Archives.

Proctor, R. W. (1994). Editorial. Behavior Research Methods, Instruments, \& Computers, 26, 271.

RESCORLA, R. A. (1995, spring). Editor's report: AL\&B. Newsletter of the Psychonomic Society, p. 3.

Roediger, H. L., III (1991, December 23). [Letter to Ilene Bernstein] Psychonomic Society Archives.

RoEdiger, H. L., III (1992, fall). Publications Committee. Newsletter of the Psychonomic Society, pp. 4-5.

Roediger, H. L., III (1994). Editorial. Psychonomic Bulletin \& Review, $1,1$.

Schooler, C., \& Feldman, S. E. (1967). Experimental studies of schizophrenia. Goleta, CA: Psychonomic Press.

Science Citation Index Journal Citation Reports 1993 (1994). Philadelphia, PA: Institute for Scientific Information.

SIDOWsKI, J. B. (1966). Experimental methods and instrumentation in psychology. New York: McGraw-Hill.

Sidowski, J. B. (1968). Editorial. Behavior Research Methods \& Instrumentation, 1,1 .

SIDOWSKI, J. B. (1989). Editorial: Comments on 22 years of editing. Behavior Research Methods, Instruments, \& Computers, 21, 565-567.

SIDOWSKI, J. B. (1990). Past, present, and future of the Society for Computers in Psychology. Behavior Research Methods, Instruments, \& Computers, 22, 94-97.

SiDowski, J. B. (1995, June 14). [Interview with Donald A. Dewsbury, Tampa, FL].

Social Science Index Journal Citation Reports 1993 (1994). Philadelphia, PA: Institute for Scientific Information.

SPENCE, J. T. (1976, February 23). [Memorandum to Psychonomic Journal Editors] (Psychonomic Society Archives, Box 488.1). Akron, $\mathrm{OH}$ : University of Akron, Archives of the History of American Psychology.

Thompson, R. F. (1973). Editorial. Physiological Psychology, 1, 1.

Thompson, R. F. (1976, December 8). [Letter to the Psychonomic Society membership]. Psychonomic Society Archives.

VERPLANCK, W. S. (1959a, July 4). [Letters to potential members of an Organizing Committee] (Psychonomic Society Archives, Box 510). Akron, $\mathrm{OH}$ : University of Akron, Archives of the History of American Psychology.

VerPLANCK, W. S. (1959b, July 17). [Letter to Parker S. Lichtenstein] (Psychonomic Society Archives, Box 510). Akron, $\mathrm{OH}$ : University of Akron, Archives of the History of American Psychology.

VerplanCK, W. S. (1960). Minutes of the second meeting of the Governing Board Chicago, Ill., I September, 1960 [erroneously listed as 1961 in original] (Psychonomic Society Archives, Box 488.1, Folder 22). Akron, $\mathrm{OH}$ : University of Akron, Archives of the History of American Psychology.

WILSONCROFT, W. E., \& LAW, O. T. (1967), Laboratory manual for physiological psychology. Austin, TX: Psychonomic Press.

Woods, P. J. (1961). Some characteristics of journals and authors. American Psychologist, 16, 699-701.

\section{NOTES}

1. Minutes from the Governing Board, Publications Committee, or Business meetings are cited as such in the text, but, with the excep- 
tion of Verplanck (1960), are not included among the references. These documents can be found in the Psychonomic Society Archives in the Archives of the History of American Psychology at the University of Akron; some exist in other locations as well.

2. Several items among the References are cited as in the Psychonomic Society Archives, with no further information. These are items that the author has secured from either the Publications Office in Austin or very helpful long-time members of the Psychonomic Soci- ety. The documents are in his possession at the time of writing, but are to be deposited in the Psychonomic Society Archives at the University of Akron when appropriate.

(Manuscript received November 13, 1995; revision accepted for publication April 10, 1996.) 